International Journal of Environment, Agriculture and Biotechnology
Vol-6, Issue-3; May-Jun, 2021
JUAB
Journal Home Page Available: https://ijeab.com/
Journal DOI: $10.22161 /$ ijeab

Article

Peer-Reviewed Journal

\title{
Analysis of Sustainable Potential of Kite Fish (Decapterus Spp) in the Waters of bone bay of South Sulawesi province
}

\author{
Muh. Arfah Mustari, Aris Baso, Hamzah Tahang
}

Master of Fisheries Sciences Faculty of Fisheries and Marine Hasanuddin University, Perintis Kemerdakaan Km 10 Makassar 90245 Indonesia

Received: 16 Feb 2021; Received in revised form: 25 Apr 2021; Accepted: 16 May 2021; Available online: 31 May 2021 (C2021 The Author(s). Published by Infogain Publication. This is an open access article under the CC BY license (https://creativecommons.org/licenses/by/4.0/).

\begin{abstract}
The purpose of this study is to analyze the level of exploitation of kite fish in the Waters of Bone Bay, South Sulawesi Province. This study was conducted in July to September 2021. The method used is Descriptive Quantitative by using questionnaire tools. The sampling method used is a method with a total of 10 units of Kite Fishing business each in the Bone Bay Waters area. The data analysis used is an estimate of biological parameters and Maximum Sustainable Yield. The results showed that business conditions Condition of maximum sustainable yield potential in the waters of bone bay has not been indicated to experience over fishing with the value of effort can be 64,315.46 units / year, yield of 70,161.10 tons / year and Biomass of 180,332 tons/year.
\end{abstract}

Keywords-Maximum Sustainable Yield, Kite Fish, Bone Bay Waters area.

\section{INTRODUCTION}

Kite Fish (Decapterusssp) is one of the pelagic fish caught in these waters that contributes the most. Kite fish are caught using fishing gear such as charts, gillnets, payang, and ring trawls (purse seine). This kite fish has an important role and has economic value in the fishery purse seine so much sought after and captured by the fleet of seine purse as the main target of catches (Prihartini, 2004). The approach of the biological aspect is generally used to evaluate fish resources but without neglecting the economic aspects. While fishermen as businesses and resource users are oriented to economic principles by prioritizing the greatest profit without regard to sustainability. Therefore, it is necessary to analyze the utilization rate of Catch Per unit Effort (CPUE), determination of Sustainable Potential Level, Optimum Effort, and Utilization Rate of kite fish resources in the Gulf of Bone Sea of South Sulawesi, where the information is needed in sustainable fishery management (Sangaji, et al. 2017).

In general, fishermen of the Fishing Unit operating in the Waters of Bone Bay are fishing businesses that still rely on their habits such as fishing methods, fishing areas, and fishing seasons. This resulted in the value of the production of volatile catch fisheries.Business feasibility analysis is a criterion for investment investment for a certain production period. The analysis is necessary to determine the future development of the Arrest Unit business. To support the analysis, it is necessary to calculate economic aspects such as capital, financing, revenue, and sustainability in a certain production period (Karningsih, 2014).

\section{RESEARCH METHODOLOGY}

\section{A. Location and Time of Research}

This research was conducted during 3 July September 2020. The location of this study is in Palopo City, Bone Regency and Sinjai Regency. The samples in this study were kite fish. This research was conducted in Bone Bay by taking place in 3 (three) districts that serve as fishing bases, namely Palopo City, Bone Regency and Sinjai Regency, South Sulawesi Province. The three locations are location points that represent the waters of Bone Bay, While Paying Attention to the Covid-19 Health Protocol. 


\section{B. Types of Research}

This research uses quantitative methods. Quantitative is the process of finding knowledge that uses data in the form of numbers as a tool to find information about what is the problem of research (Sugiyono, 2013). This research was conducted by conducting survey methods by conducting observations in the field and interviewing directly with respondents, as well as using questionnaires as a data collection tool. Then the data that has been obtained is analyzed quantitatively.

\section{Sampling Method}

Research methods are basically a scientific way to obtain data with specific purposes and uses. To achieve these goals, a method is required that is relevant to the goal to be achieved. The method used in this study is the survey method. Survey method is research conducted using questionnaires as a means of research conducted in large and small populations, but the data studied is data from samples taken from the population, so that relative events, distribution, and relationships between variables are found. The purpose of the survey research is to provide a detailed picture of the background, traits, and characteristics typical of the case or occurrence of a common thing (Sugiyono, 2013).

Sampling techniques that will be used in this study are determined by consideration of the terms of representation of aspects of the study and analysis needs, Sampling methods used are non probability sampling that is by purposive sampling where, data collection techniques from interview results and direct observations purposively to several stakeholders related to kite fishing activities respondents are considered to have the ability to answer questions asked well and can understand the problems that exist.

Samples are part of the number and characteristics owned by the population (Sugiyono, 2008) Purposive sampling is a technique of determining samples with certain considerations that is based on the purpose of research. This is done to obtain samples that fit the criteria or research objectives to obtain and obtain accurate data. The criteria in this study focused on Fishermen, Collectors, and Retailers.

The respondents selected are those who know internally and externally the condition and are able to provide answers and confirmations about the questions asked by way of interview (depth interview)

\section{.D. Population and Research Samples}

The data required in this study are information related to kite production data, number of kite fishing fleet, operational costs and others. In order to obtain these data, the first thing to do is to determine the research population so that this research gets clarity on the subject of the research. Population is a group consisting of objects or subjects that have certain qualities and characteristics set by researchers to be studied and then drawn conclusions (Sugiyono, 2013).The population of this study is fishermen who have a kite fishing business using seine purse fishing equipment. Based on data from the Department of Marine Affairs and Fisheries, the number of kite fishing efforts with seine purse fishing equipment in Bone 9 units, Palopo City 12 units and Sinjai Regency 120 units.

The sample is a portion of the population that has the same characteristics as the population. Sampling techniques in this study using purposive sampling technique (Sugiyono, 2013). The selection of this technique is based on a specific research study, namely the bioeconomic assessment of kite fish in the waters of Bone Bay. The sample is part or representative of the population to be studied (Suharsimi, 2014). Sampling for research according to Suharsimi (2014), if the subject is less than 100 people should be taken all of them, if the subject is large or more than 100 people should be taken $10-15 \%$ or $20-25 \%$ or more. So for Sinjai district exceeds 100 units, researchers take $10 \%$ of the population so that the sample used as many as 10 units.

E. Data Analysis

Data Analysis used in this study as follows:

To answer the formulation of the first problem about the exploitation of fish Data used in the method of Surplus Production in the form of catches and efforts, then conducted data processing through the Dynamic Model approach which is a model of regression analysis of CPUE to the amount of effort.

1. Catch per Unit Effort (CPUE)

After the production and effort data (input or effort) is arranged in the form of time sequence according to the type of capture tool, the next step is to look for the catch per unit of effort (CPUE).. CPUE values can be notified as follows:

$$
\begin{gathered}
\text { CPUE }_{\mathrm{t}}=\frac{\text { Catch }_{1}}{\text { Effort }} \\
\mathrm{t}=1,2, \ldots \mathrm{n}
\end{gathered}
$$

Where:

CPUEt $=$ catches per capture attempt in the $t$-year

Catch1 $=$ catch in the $\mathrm{t}$-year

2. Standardization of fishing gear

Standard fishing equipment is based on the amount of catch obtained as well as the 
amount of fishing power index value (FPI) with input (effort/ effort) of standardized tools.

$$
\mathbf{E}_{\text {std }}=\mathbf{Y}_{\text {tot }} / \mathrm{CPUE}_{\text {std }}
$$

Where:

Estd : Efforts /efforts fishing standards CPUEstd : CPUE Standard Capture Tool

Ytot: CPUE that is used as standard

\section{Estimation of Biological parameters}

Biological parameters include water carrying capacity constant (K), natural growth constant (r), technology parameter (q). While the economic parameters include the cost per catching effort (c/p), the price of IkanLayang per unit, the catch (p), and the rate of deduction / discoun rate. There are several approaches in estimating biological parameters, but in this study used is the model of estimation of CYP (Clark, Yoshimoto and Pooley) with the approach and development of the formula model Fox (1970) and Schunate (1977), systematically the equation is written as follows: Clark et al., (1992) with model 4:

\section{$\operatorname{Ln}\left(\mathrm{CPUE}_{\mathrm{t}+1} / \mathrm{CPUE}_{\mathrm{t}}\right)=\beta_{0}+\beta_{1} \mathrm{CPUE}+\beta_{2} E_{t}+\mathrm{e}$}

Where:

CPUEt $+1=$ CPUE at $t+1$ time

CPUEt $=$ CPUE at time $\mathrm{t}$

$\mathrm{Et}=$ Effort at time $\mathrm{t}$

$\mathrm{Et}+1=$ Effort at time $\mathrm{t}+1$

$\beta 0=$ coefficient of intercept rgresi result

$\beta 1=$ coefficient $X$ variable 1 regression result

$\beta 2=$ coefficient $X$ variable 2 regression result

Estimation of Biological parameters

Biological parameters include water carrying capacity constant $(\mathrm{K})$, natural growth constant (r), technology parameter (q). While the economic parameters include the cost per catching effort $(\mathrm{c} / \mathrm{p})$, the price of kite fish per unit, catches (p), and the rate of deduction / discoun rate. There are several approaches in estimating biological parameters, but in this study used is the model of estimation of CYP (Clark, Yoshimoto and Pooley) with the approach and development of the formula model Fox (1970) and Schunate (1977), systematically the equation is written as follows: Clark et al., (1992)

4. Maximum Sustainable Yield (MSY) Analysis

Calculation of the Maximum Sustainable Yield (MSY) model using the equation:

$$
\begin{aligned}
\text { EMSY } & =\mathbf{r} / 2 \mathbf{q} \\
\mathrm{YMSY} & =\mathrm{Kr} / 4
\end{aligned}
$$

\author{
$\mathrm{XMSY}=\mathrm{K} / \mathbf{2}$ \\ where: \\ EMSY : Attempts to capture MSY's condition \\ YMSY : MSY condition capture \\ XMSY : Estimating optimal stock of MSY \\ conditions
}

\section{RESULTS AND DISCUSSION}

\section{A. Kite Fishing Equipment}

Purse seine is often referred to as a bag net because the shape of the net when operated is shaped like a pouch Where in determining the design is based on the fish that is the purpose of catching, the catching area, as well as the method of catching that will later be applied and the seine purse ship to be used. Purse seine itself is the most effective fishing tool to catch hordes of fish that are on the surface (pelagic fish) which in operation can be done by chasing hordes of fish, or by using fish collecting aids in the form of lamps or rumpons.

Purse seine itself has a rectangular shape with pockets on the edges, this shape is called a type of shawl. Most of the net material is made of polyamide measuring 400 meters with a depth of 100 meters and a mesh size of $25 \mathrm{~mm}$ (1 inch). Has a weight of 180 pieces made of lead with a weight of $2 \mathrm{~kg} /$ piece each. In addition, it is equipped with a buoy sign and 2300 net buoys made of plastic with a ball-like shape that has a diameter of $10 \mathrm{~cm}$ (4 inches).

In the operation of purse seine departure to the location of arrest is carried out in the morning (09.00 Wita) and there is also during the day (13.00 - 16.00 WITA) depending on the distance or nearby fishing ground. If the location of the fishing ground is classified as far away then the departure is done in the morning and if the fishing ground is relatively close then the departure is done during the day. After arriving at the fishing ground, the light boat was removed from the ship and the ABK tethered the rope to the rumpon, and in the afternoon at 18.00 Wita the main light was turned on to attract hordes of fish.

\section{B. Catch Per Unit Effort}

Can be seen from 2010-2019 CPUE some fishing tools tend to be volatile. CPUE some of the highest fishing gear in 2017 was 0.4779 tons per unit and the lowest occurred in 2010 at 0.0408 tons per unit.

The possibility of decreased CPUE is also due to the increasing distance of the catchment area and due to the influence of changes in natural/environmental conditions (weather, wind, salinity, seasons) on population and resource communities. 
Table 1. The amount or value of the catch per unit effort (CPUE) describes or reflects the productivity level of the effort.

\begin{tabular}{llllllll}
\hline Tahun & Payang & PukatCincin & JaringInsangHanyut & JaringInsangTetap & $\begin{array}{c}\text { Bagan } \\
\text { Perahu }\end{array}$ & $\begin{array}{c}\text { Bagan } \\
\text { Tancap }\end{array}$ & $\begin{array}{c}\text { Pancingulur } \\
2010\end{array}$ \\
& 0.0363 & 0.0408 & 0.0209 & 0.0001 & 0.0049 & 0.0003 & 0.0079 \\
2011 & 0.1554 & 0.0715 & 0.0086 & 0.0014 & 0.0281 & 0.0016 & 0.0024 \\
2012 & 0.1143 & 0.0836 & 0.0028 & 0.0011 & 0.0251 & 0.0019 & 0.0009 \\
2013 & 0.0278 & 0.0888 & 0.0026 & 0.0013 & 0.0190 & 0.0038 & 0.0000 \\
2014 & 0.0965 & 0.4094 & 0.0083 & 0.0062 & 0.0958 & 0.0243 & 0.0002 \\
2015 & 0.0828 & 0.3477 & 0.0071 & 0.0052 & 0.0813 & 0.0207 & 0.0002 \\
2016 & 0.0947 & 0.3936 & 0.0080 & 0.0059 & 0.0921 & 0.0234 & 0.0002 \\
2017 & 0.1024 & 0.4779 & 0.0086 & 0.0064 & 0.0986 & 0.0251 & 0.0002 \\
2018 & 0.1045 & 0.4600 & 0.0087 & 0.0065 & 0.1006 & 0.0256 & 0.0002 \\
2019 & 0.1086 & 0.4391 & 0.0091 & 0.0067 & 0.1046 & 0.0266 & 0.0002 \\
\hline
\end{tabular}

Source : Secondary Data after processing, 2021

\section{Standardization of Fishing Gear}

Standardization of fishing equipment is required to homogenize kite fishing steam consisting of various types of fishing equipment. Determination of standardization of effort units in this study is the total effort per year of several fishing equipment with time series data in 2010-
2019 obtained from the Fisheries Service palopo city, Bone regency and Sinjai regency of South Sulawesi Province. The standard fishing gear used in this study is Purse Seine on the grounds that it has a greater catch perunit effort value compared to other fishing gear.

Standardization of Kite Fishing Equipment in the Waters of Bone Bay, South Sulawesi Province in 2010-2019

\begin{tabular}{ccccccccc}
\hline Tahun & Payang & PukatCincin & JaringInsangHanyut & JaringInsangTetap & $\begin{array}{c}\text { Bagan } \\
\text { Perahu }\end{array}$ & $\begin{array}{c}\text { Bagan } \\
\text { Tancap }\end{array}$ & Pancingulur \\
\hline 2010 & 0.8889 & 1.0000 & 0.5127 & 0.0025 & 0.1203 & 0.0082 & 0.1943 \\
2011 & 2.1733 & 1.0000 & 0.1200 & 0.0195 & 0.3935 & 0.0227 & 0.0341 \\
2012 & 1.3664 & 1.0000 & 0.0340 & 0.0132 & 0.2999 & 0.0227 & 0.0113 \\
2013 & 0.3135 & 1.0000 & 0.0291 & 0.0141 & 0.2139 & 0.0426 & 0.0005 \\
2014 & 0.2358 & 1.0000 & 0.0203 & 0.0151 & 0.2339 & 0.0594 & 0.0005 \\
2015 & 0.2382 & 1.0000 & 0.0203 & 0.0151 & 0.2339 & 0.0594 & 0.0004 \\
2016 & 0.2406 & 1.0000 & 0.0203 & 0.0151 & 0.2339 & 0.0594 & 0.0004 \\
2017 & 0.2144 & 1.0000 & 0.0179 & 0.0133 & 0.2064 & 0.0525 & 0.0004 \\
2018 & 0.2271 & 1.0000 & 0.0190 & 0.0141 & 0.2187 & 0.0556 & 0.0004 \\
2019 & 0.2473 & 1.0000 & 0.0206 & 0.0153 & 0.2382 & 0.0605 & 0.0005 \\
\hline
\end{tabular}

Source : Secondary Data after processing, 2021

Table 4. Productivity level of (effort) after strandarization of kite fishing equipment in the Waters of Bone Bay, South Sulawesi Province in 2010-2019 


\begin{tabular}{crrr}
\hline Total & Produksi (Ton) & Total Effort Standard & CPUE (Total/Unit) \\
\hline 2010 & $2,918.60$ & 71,456 & 0.0408 \\
2011 & $5,670.10$ & 79,305 & 0.0715 \\
2012 & $6,132.00$ & 73,321 & 0.0836 \\
2013 & $5,859.30$ & 65,990 & 0.0888 \\
2014 & $22,815.30$ & 55,732 & 0.4094 \\
2015 & $19,571.70$ & 56,285 & 0.3477 \\
2016 & $22,377.80$ & 56,848 & 0.3936 \\
2017 & $24,449.80$ & 51,163 & 0.4779 \\
2018 & $25,183.29$ & 54,745 & 0.4600 \\
2019 & $26,442.46$ & 60,219 & 0.4391 \\
\hline
\end{tabular}

Source : Secondary Data after processing, 2021

3. Estimation Parameter Biology

From the value obtained is then incorporated into the equation of biological parameters so that it can be suspected constants of fish growth rate, coefficient of fishing and constants of water carrying capacity.

The estimated result of the three parameters presented in table 1, The value can be seen in table 5

Table.5: estimated result Value

\begin{tabular}{clccc}
\hline \multirow{2}{*}{ No } & \multirow{2}{*}{ Estimasi } & \multicolumn{3}{c}{ Parameter Regresilkan Layang } \\
\cline { 3 - 5 } & & $\boldsymbol{\beta}_{\mathbf{0}}$ & $\boldsymbol{\beta}_{\mathbf{1}}$ & $\boldsymbol{\beta}_{\mathbf{2}}$ \\
\hline 1 & Coefficients & 1.97509529 & 4.1489335 & $1.1713 \mathrm{E}-05$ \\
2 & Standard Error & 0.67503034 & 0.4744975 & $8.7529 \mathrm{E}-06$ \\
3 & t Stat & 2.9259356 & 8.743847 & 1.33812742 \\
4 & F & 293.705984 & & \\
5 & R Square & 0.98988898 & & \\
\hline
\end{tabular}

Source : Secondary Data after processing, 2021 
Ordinary Least Squares (OLS) models from Table 5 for Kite Fish are as follows

$\mathrm{Y}=\mathrm{y}=-2 \mathrm{E}-05 \mathrm{x}+1.9750 \mathrm{R} 20.99$ From the data contained in table 5 it appears that the R2 value of IkanLayang is 0.99 , this indicates that independent variables in the equation have a strong influence and association with dependent variables. From the value obtained is then incorporated into the equation of biological parameters so that it can be suspected constants of fish growth rate, coefficient of fishing and constants of carrying capacity of fish waters itself. The estimated results of the three parameters presented in table 5, useful for determining the level of sustainable production such as maximum sustainable yield (MSY)

\section{Maximum Sustainable Yield}

The key assumption of the sustainable potential model or sustainable harvest in maximum sustainable yield (MSY) is that the population of IkanLayang grows and replaces itself, in the sense that the population of IkanLayang is a renewable resource. The concept of sustainable catchment or Maximum Sustainability Yield (MSY), aims to maintain the size of the population at the maximum point where the growth rate with harvesting is will usually be added to the population and allow the population to be productive forever (Hertiniet al., 2013). To determine sustainable catches or sustainable potentials, a maximum sustainable yield management regime is used.

Table 6. Maximum Sustainable Yield of Kite Fish.

\begin{tabular}{cccc}
\hline Model & $\begin{array}{c}\text { Effort } \\
\text { (Unit) }\end{array}$ & $\begin{array}{c}\text { Yield (Y) } \\
\text { (Ton) }\end{array}$ & $\begin{array}{c}\text { Biomass (X) } \\
\text { (Ton) }\end{array}$ \\
\hline MSY & $64,315.46$ & $70,161.10$ & $180,332.20$ \\
Aktual & $62,506.41$ & $16,142.04$ & \\
\hline
\end{tabular}

Source : Secondary Data after processing, 2021

Based on Table 6 that has been analyzed using the maximum sustainable yield management regime model, the effort value can be 64,315.46 units / year, yield of $70,161.10$ tons / year and Biomass of 180,332.20 tons / year, while in actual production conditions of $62,506.41$ tons

Table 2. Standardization of Kite Fishing Equipment in the Waters of Bone Bay, South Sulawesi Province in 2010-2019

5. Level of Kite Fish Exploitation in Bone Bay Waters The availability of fish is also influenced by environmental factors (oceanographic condtions) so that changes in oceanographic conducives affect the produtivtas of the waters which then impact the distribution of fish. Fish distribution will affect fishermen's actions in the allocation of fishing (Nelwan, 2016).

To prevent excessive fishing, a fishery management effort is needed to keep fish resources sustainable. In fishery management it is not easy to regulate and change the existing circumstances so that the way that is possible is to conduct a surveillance system on ships entering the waters, especially for catchers who enter the waters that are not the catchment area and conduct a data collection system on fish production as a whole whether it is against fish that are worth selling, consumption, or wasted. From the results found in the field, there are still many fishermen's catches that have not been recorded thoroughly.

Fishing efforts can be known from the data of kite production although has been described data recorded in various fisheries services three regions such as Bone, Sinjai and Palopo have not been thoroughly or not fully recorded. Fluctuations in the utilization rate of kite fish (Decapterussp) seen from the data of kite fish production can be caused by various factors, the decrease in catch may be due to the decrease in population size due to high fishing efforts in previous years. On the contrary, increased catches can be due to increased population size due to low arrest attempts in the previous year, or increased efforts themselves due to price pushes.

To determine the level of exploitation of kite fish, where the level of exploitation of kite fish is directly related to the sustainable potential (MSY) of fishery resources and kite fishing efforts. By knowing and analyzing the level of exploitation, it is expected that a balance between the sustainable potential (MSY) of fishery resources and their utilization so that the sustainability of fishery resources can be guaranteed.

\section{CONCLUSION}

The condition of maximum sustainable yield potential in bone bay waters has not been indicated to be over fishing with the value of effort can be $64,315.46$ units / year, yield of 70,161.10 tons / year and Biomass of $180,332.20$ tons / year

\section{REFERENCES}

[1] Fujii, Y., Iriana, W., Okumura, M., Lestari, P., Tohno, S., Akira, M., \& Okuda, T. (2012, December). Characterization of biomass burning aerosols from forest fire in Indonesia. In AGU Fall Meeting Abstracts (Vol. 2012, pp. A21A-0030).

[2] Gemaputri, A. A. 2013. Tingkat Pemanfaatan Sumber Dayalkan Hasil Tangkapan Di PerairanJember Utilization Rate Of Fish Resources In Jember Water. JurnalPerikanan (J. Fish. Sci.) Xv (1): 35-41 ISSN: 0853-6384 
[3] Hamka, E dan M. Rais. 2016. Penentuan Musim PenangkapanIkan Layang (Decapterus Sp.) Di Perairan Timur Sulawesi Tenggara Determination Of

[4] Hertini, E dan N. Gusriani. 2013. Maximum Sustainable Yield (MSY) pada PerikanandenganStruktur Prey-Predator. Prosiding Seminar Nasional Sains dan Teknologi Nuklir. PTNBR - BATAN Bandung.

[5] Kawarnidi, F., Labaro, I. L., \&Silloy, F. (2018). Komposisi Hasil Tangkapan Jaring Insang Dasar di perairan Desa Talise Tambun, Kecamatan Likupang Barat (Composition catches of bottom Gill Net in Talise Tambun Waters of Likupang Barat District). Jurnalllmu dan Teknologi Perikanan Tangkap. https://doi.org/10.35800/jitpt.3.1.2018.18906

[6] King M. 1995. Fishery Biology, Assessment, and Management. Fishing News Books. London.

[7] Latuconsina, Husain.2010. Eksistensi Sasi Lautdalam Pengelolaan Perikanan Berkelanjutan Berbasis Komunitas Lokal Di Maluku.Jurnal Triton Volume 5, Nomor 1, April 2010, Hal. $63-71$. 